AperTO - Archivio Istituzionale Open Access dell'Università di Torino

\title{
Party Patronage in Italy: A Matter for Solitary Leaders
}

\section{This is the author's manuscript}

Original Citation:

\section{Availability:}

This version is available http://hdl.handle.net/2318/1632674

since 2018-03-14T13:18:06Z

Publisher:

Oxford University Press

Published version:

DOI:10.1093/acprof:oso/9780199599370.003.0012

Terms of use:

Open Access

Anyone can freely access the full text of works made available as "Open Access". Works made available under a Creative Commons license can be used according to the terms and conditions of said license. Use of all other works requires consent of the right holder (author or publisher) if not exempted from copyright protection by the applicable law. 


\section{Fabrizio Di Mascio}

\section{Patronage in Italy: \\ A Matter for Solitary Leaders}

\section{INTRODUCTION}

Italy constitutes a crucial case for the investigation into changes of patronage practices in contemporary democracies. According to Kopecky and Scherlis (2008), the so-called Italian "First Republic" was in fact a paradigmatic case of the diffusion of "bureaucratic clientelism" characterised by: a) the distribution of an enormous quantity of posts at all levels of the administration, and; b) the presence of reward as the dominant motivation behind political appointments.

Bureaucratic clientelism is held to occur in South European systems which share historical developments that have produced administrative systems distinct from the Weberian ideal type. Administrative organisation and behavior have been shaped by the Napoleonic tradition widely diffused in Southern Europe (Peters 2008). The emphasis on state power over the role of society that distinguishes Napoleonic tradition conforms to the role of the State in Southern societies of “assisted capitalism” (Sotiropoulos 2004). The State in Italy has traditionally promoted economic development through strategies and instruments (protectionism, transfers, subsidies, control of industries) used in a very particularistic fashion. The long-term dependence of the Italian weak bourgeouisie on the State has prevented distributional particularism from being reviewed by the rise of Weberian administrative structures (Amato 1979).

An administrative system with low institutional capacity, affected by multiple organisational and functional contradictions, has thus resulted from historical development (Cassese 1993). The Italian system has long displayed the features typical of the prevalent southern European bureaucratic model: a) patronage at the bottom, clientelistic patterns in the recruitment of lowranking officials; b) formalism and legalism complemented by informal shadow governance structures; c) uneven distribution of resources, institutional fragmentation and insufficient mechanisms for policy-coordination; e) absence of a typical European administrative élite (Sotiropoulos 2004). 
An administrative elite equipped with an esprit de corps has never formed due to the lack of highly selective recruitment channels. The Italian administrative elite has been described as an "ossified world" (Cassese 1999) elderly and with little professionalisation, where promotions were rewards for age and length of service, without horizontal and vertical mobility, dominated by the formalism of personnel almost exclusively trained in law. The low level of professionalism allowed the top ministerial bureaucracy to form a pact of reciprocal self restraint with politicians. The pact was based on the exchange between job security and political power: bureaucrats renounced an autonomous and pro-active role in processes of policy-making, while parties refrained from interfering in the management of careers - the primary preoccupation of a bureaucracy gone 'southern', characterised by a patrimonial conception of public service, dedicated to administrating itself rather than the country. The roots of the exchange between job security and political power can also be traced back to the key features of the old "polarized pluralism" (1947-1992): tripolar centrifugal competition and centre occupied by the DC that made any total alternation in power impossible (Sartori 1976). Due to the low average duration of unstable coalitions, ministers did not have the time to gain control of their departments, nor had they the motivation to do so in such a short-term perspective.

"Patronage at the top", a key feature of Southern systems, has not been extensive in the ministerial domain, while it has flourished in the Italian parallel administration, "a complex and probably unique mélange of parastatal bodies, public agencies and public corporations" (Golden 2003, 202), marked by increasing extension and plurality of organisational models. Parties have pursued a strategy of colonisation (Sartori 2005) by penetrating via party-nominated appointees all spheres of Italian society which came under full control of, or largely dependent upon, the parties' organisational networks entrenched within an overgrown public sector.

The deep colonisation of an "available State" (Di Palma 1979) constituted the condition for the affirmation and reproduction of partitocrazia, a regime at first characterised by the substantial monopoly of parties over political activity and, later, by the progressive expansion of their power into the social and economic spheres (Pasquino 1995). The legitimacy deficit of the Italian democracy has been compensated by the organisational strength of its political parties which dominated the political system (Morlino 1998). The weakness of public bureaucracies, the interventionist tradition of the State in the economic sector, and the necessity to mantain the precarious consensus for a regime affected by exclusive legitimation, have thus conferred relevance to patronage as a crucial resource in the Italian pattern of democratic consolidation. 


\section{Between party system change and administrative reforms: Italy as a transitional context}

At the beginning of the 1990s changes in the international environment shook the foundations of partitocrazia: the end of the two bloc system of international relations sanctioned the definitive erosion of the bases of systemic polarisation that had determined electoral and governmental alliances; the parties in government also saw the growth of constraints imposed by the process of European integration on the irresponsible particularistic distribution of material resources (Cotta 1996). The exhaustion of ideological polarisation and material public resources, which had fed competition among the old parties, accentuated the turbulence in the internal environment. International changes facilitated the launching of challenges to partitocrazia by various actors that provoked the increasing destructuration of parties and the party system. Between 1992 and 1994, "atomisation" was reached, characterised by exceptional fluidity and uncertainty as much in party organisations as in their systemic interactions (Di Virgilio 2006).

It was in 1994 that a new process of consolidation of the party system began. The introduction of new electoral laws as a majoritarian institutional arrangement precipitated the collapse of the old parties and stimulated the consolidation of a new set of competitive interactions. The party system had undergone a radical transformation: most of the parties participating in the 1994 election were either brand new or had been affected by a profound change. The party system has assumed the features of "fragmented bipolarism" (D’Alimonte 2005). Systemic atomisation has been overcome thanks to a new two-level system composed not only of parties but also of pre-electoral coalitions. The alternation in government between pre-electoral coalitions has become the new predictable structure of competition (Cotta and Verzichelli 2000). If pre-electoral coalitions have provided for the re-freezing of the party system, the single party organisations have remained thawed, as demonstrated by the party supply, incessantly re-modelled by fissions and fusions of party labels. Atomisation has been overtaken by change in the party system, but this has left a legacy of crisis among parties as organisations with scarce or absent levels of institutionalisation. The nature of governmental coalitions is still fragmented and heterogenous, heightened by the uncertainty of a system where only the bipolar mechanics has been stabilised while the format has remained subject to fluidity.

The collapse of the old parties, that have been unwilling to modify a dysfunctional bureaucratic machine, created a unique window of opportunity for administrative reforms that profoundly reshaped three dimensions of the Italian State (Lewanski 1999; Natalini 2006). The first dimension 
is the substantial retreat from direct intervention and entrepreneuship in the economy in favour of a regulatory role. Independent autorithies have been created to regulate liberalised markets, while privatisation processes have radically reduced the size of the State and reorganised the remaining public enterprises into shareholder companies controlled by Treasury.

Up to the late 1980s Italy had one of the largest state-owned sectors among Western economies: 12 out of the 20 largest non financial companies were state-owned and 90 per cent of financial investment was provided by state controlled banks. The turning point came in 1992 when a public finance and currency crisis materialised. Privatisation in Italy produced the second highest revenues in Europe after the UK. Real progress has been made since the mid-1990s in reducing the debt-to-GDP ratio which amounted to 124.8 per cent in 1994. Privatisation was a main component of the restrictive budget policy pursued in order to meet the criteria to join the EMU. Between 1995 and 2000 the government spending as percentage of GDP fell from 52.5 to 46.2. Nonetheless, Italy still has one of the highest debt-to-GDP ratio which amounted to 105.8 per cent in 2008 (EUROSTAT).

The second component of the process of reform is the change in the organizational structure of central administration: organisational flexibility has increased, taking a large share of the regulation of the administrative machinery away from the Parliament and into the hands of the executive in order to implement a permanent policy of organisational rationalisation (Lupo 2003); public management reform reinforced powers and responsibilities of senior executives in administrative management; the increase in the autonomy of public managers has been balanced by the growth of ministerial discretion in the awarding of fixed term contracts to senior executives who lost tenured positions.

The third dimension of the reshaping of the Italian State is the reform of subnational government: legislative powers and administrative functions have been decentralized; subnational executives have been reinforced thanks to institutional reforms that introduced semi-parliamentary forms of government; subnational executives acquired wide regulatory powers over subnational administrative structures; enhanced organisational flexibility has led to a sharp growth in the number of local disaggregated institutions.

After reforms, local governments represent a larger share of total expenditures (31.3\%) than they do for revenues $(19.1 \%)$, and finance 54.3 per cent of these expenditures through grants/transfers (OECD). The share of total government staff employed at central level is still high and it amounted to 58 per cent in 2008. Government employment in Italy as a share of the total labour force amounted to 14.7 per cent in 2007 (Torchia 2009). The corporatisation of governments in periphery has created a wide semi-public sphere composed of local enterprises which amounted to 4874 units 
in 2005 (Citroni 2009). The universe of local corporations is the expanding semi-public appendage of the already fragmented galaxy of Italian public institutions shown by Table 1 .

- Table 1 About Here -

\section{THE EMPIRICAL ANALYSIS}

The empirical analysis that follows proposes to ascertain how far the radical changes of the 1990s have affected the diffusion, logic and mechanisms of patronage. The analysis aims to fill a gap in the greater part of the literature, which continues to associate Italy with the old patronage practices that developed in a political-administrative context overturned by the crisis of the 1990s.

For each policy sector five experts have been interviewed, leading to a total of 45 interviews. Figure 1 displays the distribution of interviews. Respondents have a varied background: from top civil servant, politicians and academics, to journalists and other specialists with deep knowledge in policy sectors under investigation.

\section{- Figure 1 About Here -}

Compared to the practices of bureaucratic clientelism of the old partitocrazia, the political and administrative changes of the 1990s have altered: i) the diffusion of patronage at the central level of government, which has clearly shrunk because external policy constraints have narrowed the State's hold on the economy and reduced the extent of party penetration; ii) the mechanisms for forming bonds of trust between politicians and appointees, which are no longer governed by party organisations but based on personal networks. 
Patronage is still pervasive in the Italian public sector. The analysis of formal opportunities for patronage practices reveals the high susceptability of Italian public bodies to party influence over the distribution of positions. Political appointments are actually allowed by the legal framework for most institutional types of all policy sectors and parties make use of existing opportunities to fill in positions with political appointees. The only institutional sub-type that remains formally unaffected by patronage is the executing level for the Judiciary.

Table 2 presents the Index of Patronage scores. Ministerial Departments are the institutional type where patronage is more pervasive. It is followed by Non-Departmental Agencies and Commissions and Executing institutions which remain less penetrated by patronage practices.

\section{- Table 2 About Here -}

Data on the range and depth of patronage offer a more differentiated picture of patronage across institutional types and policy sectors. Table 3 highligths that range values are rather high at the central level of government. Scores are extremely high in Ministries and NDAs. Lower but still relevant is the width of patronage in Executing Institutions which is due to the presence in this institutional sphere of impermeable organisations operating in policy sectors such as Judiciary, Education, Military, Foreign Services and the Military.

- Table 3 About Here -

The relevance of political influence is very low in the judicial offices because distribution of posts is doled out among the organised factions of the magistracy. Associated magistracy exploits its own quantitative and qualitative power at the heart of the CSM, the Judiciary's self-governing body, which is the repository of the formal power of nomination. The legal framework makes less permeable the Education and Culture sector, where the complexity and rigidity of formal recruitment procedures protect the public school system from political interference. The strictly hierarchical organisational structure contributes to maintaining substantially impenetrable executing institutions in the Military and Police sector, such as the Armed Forces and the Fire Brigade, both of which are composed of professional bodies that privilege technical-bureaucratic rather than political criteria in internal career paths. The motivation valid for the Armed Force also hold for the Ministry of Defence, the only ministerial institution to remain unaffected by patronage. The strength of corps makes political penetration particularly difficult in military institutions where seniority and bureaucratic solidarity are the guiding criteria in the awarding of posts. The low range 
of the executing institutions of the Foreign Affairs sector is motivated by the low strategic salience of many of these institutions (consulates and a large share of embassies), which leads parties to concentrate their efforts on a few organisations (permanent representations, embassies and institutes of culture that operate with strategic partners) that require a strict congruence between the policy orientations of the executive and administrative action. In the Financial sector, finally, the Bank of Italy continues in its tradition of impermeability thanks to the complexity of its institutional mission, which requires the awarding of posts according to strictly merit-based criteria.

Table 4 shows that the depth of patronage does vary across the institutional spheres. The depth of patronage decreases in extra-ministerial domains at the central level of government. Political appointments tend to be restricted to the top level of disaggregated institutions.

- Table 4 About Here -

According to the experts, the professionalisation of intermediate and lower levels is a condition necessary for the functional autonomy of organisations that have been disaggregated from the ministries in order to operate efficiently in turbulent environments. Limiting politicisation to top positions allows disaggregated institutions such as IRAs and SOEs to conserve the high levels of organisational flexibility necessary to remain connected to dynamic transnational networks of economy and governance.

The analysis of the scope of patronage shows that Italian parties cast an extensive net of political appointments over the fragmented administration that is more dense in the ministerial centre. Patronage is more pervasive in ministerial departments because of the complexity of policy coordination performed by these institutions that organise flows of communication between different policy sectors, different levels of government, and between the State and social actors (Media and organised interests).

As can be seen in Figure 2, subnational administrations stand out as the heartland of patronage in contemporary Italy.

- Figure 2 About Here -

Parties can reach all institutions at the subnational level of government. The maximum score of range highlights the pervasiveness of local patronage that has been reinforced by the sharp increase in the number of disaggregated institutions. Parties have taken advantage of the opportunities that the expansion of subnational administration offered to fill with political appointments at all levels extra-ministerial organisations created from scratch. Moreover, the adoption of the enterprise formula in the regional healthcare systems has not succeeded in depoliticising local healthcare 
authorities which constitute arena of massive party rent-seeking. Subnational governments lacks professional bodies as hindrance to patronage expansion, since they do not operate in policy sectors characterised by established career paths. Besides professional reasons, it must be noted that feeble pressures by the EU for the liberalisation of local public service markets allowed subnational governments to extend their hold over local economies, using corporatization in order to increase the sphere of particularistic exchange which, at the local level, and especially in Southern Italy, is clearly wider and deeper than at the national level.

\section{Logic and mechanisms of patronage}

For most intervieews, political appointments are made primarily for controlling public institutions. Figure 3 highlights the prevalence of control over reward. Reward was never cited as the single motivation behind patronage. Regardless of the high score for "Both Reward and Control", control appears to be much more predominant than reward.

- Figure 3 About Here -

The logic of patronage in Italy is mainly guided by the desire to allow party governors to control the processes of policy-design and implementation and the flow of public resources in all sectors of the central administration. Parties nominate loyal individuals to top strategic positions (senior executives, board members, public corporation managers) in order to render the administrative structures more responsive to changes in policy priorities.

Patronage as control at the top is pervasive, and has not been eradicated by the administrative reforms that aimed to rationalise the functioning of the State. The reforms reduced the scope of patronage at the top through processes of privatisation, but they did not trigger a paradigm change. Administrative reforms were rather used as strategies for enhancing the flexibility of political control over the administration through the introduction of fixed-term contracts for top positions and the frequent reorganisation of public institutions. The permanent policy of rationalisation of administrative structure provoked an expansion of patronage. Both coalitions used arguments for rationalisation as an excuse for distributing new positions. Parties in government have transformed the flexibility of the legal framework into an instrument that creates room for manoeuvre in the allocation of administrative positions.

Control of the administration has not only remained widespread, it has become even thicker. The swarms of policy advisors and consultants that crowd ministerial cabinets offering specific 
expertise, flexible support and unconditional loyalty in the development of policies have expanded. The growth of ministerial cabinets as centres of power and communication in the machinery of government increases the imbalance between political control and professional policy advice that marks Italy, where ministers avoid the rigidity of bureaucracies through informal mechanisms of politicisation that allow a faster and more penetrating control of public institutions.

The exception to the prevalence of control over reward is the Regional and Local Administration sector, where experts have underlined the equal importance of the two motivations. The relevance of patronage as reward in this sector is confirmed by the fact that Regional and Local Administration has the highest scores for depth of patronage. Experts have pointed to the continued relevance of patronage as a mode of clientelistic exchange of votes for public posts at lower levels, particularly in the south of Italy where local administrative bodies continue to serve as social shock absorbers $^{1}$. Patronage as a reward for the participation of activists otherwise inactive is however widespread in Regional and Local Administrations.

The picture changes at the national level. As highlighted by the scores on the depth of patronage, in the central administration the clientelistic offer of jobs is now residual. Parties continue to play a role in the recruitment of lower level employees in some executing institutions of the economic sector, for example the Postal Services, but such interventions have been defined as marginal by experts. Patronage as a reward at the national level is therefore restricted to the supply of top positions and intermediate managerial posts to activists and professional politicians, but nevertheless to a lesser extent than seen in subnational bodies.

The ministerial sphere is a particularly relevant one for patronage as reward, allowing parties to offer their supporters positions in ministerial cabinets and intermediate bureaucratic positions open to parties' friends appointed as "in-and-outers". The boards of disaggregated organisations, particularly in the executing institutions of the Economy (SOEs) and Culture and Education (Research bodies and companies of the Ministry for Cultural Heritage), constitute the other group of institutions that provide a great many positions for distribution as rewards. To this group must be added RAI (the public service broadcaster), infiltrated at all levels in order to reward activists and professionals of parties as campaign organisations (journalists and media consultants).

The prevalence of strategies of control in appointment processes affects the criteria parties use when selecting appointees. To occupy strategic positions that control resources crucial in processes of policy-making, parties are obliged to select individuals with at least a modicum of expertise. As can be seen in Figure 4, the professional competence of appointees is a necessary but not a sufficient condition for exercising control over the State.

- Figure 4 About Here - 
Parties select appointees that are not only competent, able to manage processes of policy-making, but also loyal, ready to guarantee the responsiveness of institutions to party instructions. Parties recruit personnel that combine expertise and loyalty both to design and implement policy change and to control the particularistic distribution of services - patronage in the widest sense - to their own supporters.

Only candidates that have cultivated a network of personal relations connecting them to party actors are able to obtain a status as trustworthy and obtain positions. Public managers are no longer recruited through parties as organisations but are nominated by single party actors that draw on their personal networks embedded in the professional worlds (the public sector, the private sector, academia). The format of the party system affected the formation of links of trust between professionals and parties, as shown by the low values for political links in Italy. After the crisis of polarised pluralism, catch-all coalitions composed of numerous and fluid parties have alternated in government in Italy. The fragmentation and instability of the format of the Italian party system, resulting from the absence of consolidated loyalties towards the new parties, increases the role of personal ties in the patronage practices of new parties as pro tempore clusters of office holders gathered in catch-all blocs.

Experts underlined the collapse of political link as the most important qualification of the appointees. In the old polarised pluralism patronage practices guaranteed the deep segmentation of public institutions according to their political colours: the role of parties as organisations was relevant in covering all levels of positions entrusted to personnel chosen according to their partisan loyalty. In the new bipolar system patronage has been trasformed into a device for the personalised connection between party leadership and public bodies through the selection of professionally qualified top managers ${ }^{2}$.

The personalisation of patronage is best defined by investigating the actors that control selection processes. The relevant role of ministers, who monopolise patronage in ministerial departments and control a large share of patronage in agencies and advisory bodies for respective areas of competence, emerges sharply. The ministers with the widest networks of appointments are those for Health, Finance, and Cultural Heritage, who are able to control most of the institutions in their sectors. The institutions most open to the influence of actors other than the sector's ministers are the executing institutions (SOEs in the Economy sector, RAI in the Media sector, Research Bodies in the University sub-sector) and nonmajoritarian institutions (the Constitutional Court and the CSM in the Justice sector, Independent Authorities in the Economy and Media sectors) that are subject to the division of positions among the leaders of the coalition. The relevance of "ministers" and 
"leaders" in political appointment processes makes it difficult to mantain the distinction between organisational and governmental leadership because "the whole leadership of the 'new' Italian party system has been recruited directly at the top of government without leaving their party responsibilities" (Verzichelli 2009, 86).

The extreme personalisation of patronage has prevented managers from being organised in two compact enemy camps, despite the advent of the bipolar party system. The process of creating personal networks takes place in two phases: in the first phase each party governor gathers around her/him in her/his own personal entourage loyal expert collaborators from the sector of interest; in the next phase it is the single experts of that entourage to explore their own personal networks in search of trustworthy managers to whom a position may be given. Party governors therefore acquire the control of institutions through networks largely composed of nodes borrowed from the functional networks of their own closest collaborators. Experts have underlined the "loneliness" of party governors, who practice patronage without either close links or support from party organisations, and the ability of appointees, skilful in reaching those trusted by leaders through personal connections. The intermediation/input of the parties as organisations is missing. Experts remarked that parties as organisations play no role in processes of appointment dominated by solitary governors. The personal-functional rather than the organisational logic that informs the creation of networks also determines their fluidity: the pragmatism that dominates allows nodes with less intense relations with leaders to skip from one network to the next, activating their own personal connections that lead to both of the alliances alternating in government

\section{Majoritarian and consensual patronage practices}

The rather high value of "Jobs for the opposition" in Figure 5 is due to the presence of the practice of dividing positions between the government and opposition, concentrated in the sectors: Media, Justice, Military and Police, and Regional \& Local Administration.

- Figure 5 About Here -

In the Justice and Media sectors the distribution of positions in non-ministerial institutions among the actors of the party system is proportional with a correction for the majority. Consensual patronage practices are institutionalised by the legal framework that assigns the power of nomination to the Parliament as the arena of cooperation between the majority and the opposition. In the Justice sector the majority reserves 5 CSM posts and 3 constitutional judges for itself, 
assigning 3 CSM posts and 2 constitutional judges to the opposition. In the Media sector there is an equal division of positions on the AGCOM (Independent authority) board, 4 each, while the government reserves the choice of the President of the Authority, who enjoys wide powers in directing the organisation. In the RAI 5 members of the board are assigned to the majority and 4 to the minority, including the President. The majority select the CEO of the Company, and the top management positions of the 2 principal television networks, while the third network is marked by the prevalent and constant influence of the centre-left coalition. At the intermediate and lower levels stability prevails and the division of areas of influence among the parties resists changes in the government.

The collaboration mechanisms between government and opposition are different in the Military and Police sector. Cooperation between the two coalitions takes place in the specific sub-sector of Interior and Police and assumes the form of the sharing rather than the division of appointments. The majority enjoy the power of proposal, while the opposition evaluate the government's proposals and may veto candidates they consider incapable of offering adequate guarantees of impartiality. The sharing of the power of appointment between government and opposition is owed to the peculiarity of the sector which controls the administration of elections (Interior) and manages public order (Police). The common interest in the equality of the civil and political rights that feed the democratic process push government and opposition to consult one another so as to choose personnel loyal to both of them.

In other sectors of the central level of administration clear cut spoils system mechanisms prevail. The bipolar structure of competition creates strong pressures towards majoritarian patronage practices. The wholesale alternation in government urges coalitions to acquire exclusive control of posts considered strategic. In regional and local administration, the opposition have easier access to positions. This is particularly the case in the south of Italy because of the extreme fragmentation of party systems, characterised by the balkanisation of an extremely personalised representation. In Southern Italy parties are not even able to fulfil the procedural role of expression and support for a government. Southern executives lacking a coherent parliamentary base offer patronage opportunities to individual members of the opposition in order to build coalitions of variable geometry that ensure their precarious stability. In central and northern Italy, on the other hand, more structured party systems reinforce the control of the majority over sub-national administrations. In these areas of the country the opposition is excluded from selection processes for candidates for strategic positions, but do have stable access to numerous positions on boards of agencies and in local public utilities. 


\section{Evolution of patronage practices over time}

The collapse of the party system between 1992-1994 and the wave of administrative reforms of the 1990s brought considerable discontinuity to the patronage practices along many of the analytical dimensions examined in the project as shown in table .

\section{- Table 5 About Here -}

As far as the role of parties in policy sectors is concerned, the clear decline of political control over the Justice sector should be underlined. In the past cooperation between old parties in processes of appointment allowed them to exploit the internal divisions within the associated magistracy. Old parties were able to influence the selection of magistrates with whom they had formed strong ties. The advent of a strongly polarised party system on judicial issues has provoked a rupture in practices of exchange between coalitions. New parties are no longer able to qualitatively increase their quantitative weakness in the CSM through the old consensual arrangements which have been undermined by fierce polarisation ${ }^{3}$.

As far as the role of parties in different types of institutions is concerned, the traditional relevance of party control over "parallel administrations" (agencies and executing institutions) remains, a typical trait of the old partitocrazia. The politicisation of ministries has grown with the introduction of reforms inspired by New Public Management. The temporary nature of positions has served to ensure the loyalty more than the accountability of senior executives. Contracts are extended or managers are promoted not on the basis of their performance but on the relationship of trust they manage to establish with political leaders that distribute positions without any procedural curbs on their discretion. Patronage in ministerial departments has become a new control mechanism over policy implementation alternative to the old hierarchical supremacy of the government undermined by processes of functional and structural disaggregation. The old "ossified world" of the top civil service has become a "liquid world" where the precariousness of posts and career progression has generated the individualisation of offers of temporary loyalty to ministers of the moment. An indicator of the politicisation of ministries is the growth of senior executive positions as percentage of ministerial personnel. Between 1994 and 2007, the ratio increased from 1.8 to 2.3 (Torchia 2009), propelled by various legislative interventions of successive governments which have enlarged the quota of posts to be awarded to those from outside ministerial settings, and extended the quota of top positions to be awarded via the promotion of lower-level managers. In addition, the length of contracts has been reduced. 
Patronage as reward tends to shift to ministries, while in the First Republic it was concentrated in the executing institutions, particularly in the Economy sector. This difference in the localisation of patronage as reward is just one of the aspects of the profound change that has been observed in the executing institutions of the Finance and Economy sectors. Europeanisation and globalisation have not only notably reduced the extension of the perimeter of the public sector, they have also caused a qualitative change in patronage practices in the executing institutions, now shareholder companies that remain either wholly or partly publicly owned. The Treasury, as the only shareholder of public shares in these companies, has concentrated the management powers of publicly run companies, at one time spread out, with the intention of guaranteeing a coherent direction for all the decisions regarding public companies, and of contributing to the recovery of public finances by increasing the value of shares remaining in public hands.

The formal changes in the architecture of power over public institutions has contributed to the transformation of negotiations between parties over the division of positions. In the First Republic the dispersion of formal powers of appointment among multiple institutions gave a formal translation to deeply institutionalised practices of dividing positions, known as lottizzazione. The old parties and factions obtained posts in institutions invested with the power of appointment and, consequently, in the companies controlled by them, in proportion to their electoral strength and strategic position in the coalition. These practices were possible because old parties both could and preferred, irresponsibly, to finance the inefficiency of public companies. Enterprises and economic bodies were managed by professionals chosen on the basis of their political links and possessing the only professional quality sufficient for procuring abundant resources that hidden professionals, nominated at high and intermediate levels, arranged to distribute to clients, groups and hidden donors.

The budget constraints that centralised the formal powers of appointment in the head of the Treasury have made the division practices of the Second Republic much more unstable with respect to the old lottizzazione. The President of the Council of Ministers and the Minister for Finance have become the dominant actors in that: a) they dispose of the power to direct and control companies; and b) they represent the government in supranational organisations. Controlling information flows between markets and supranational institutions, government and public companies, the President and the Minister for Finance claim and acquire the lion's share of top management posts, thwarting the requests from allied party leaders for a more or less proportional distribution of positions during coalition bargaining. The President of the Council has extended his own sphere of influence to other important policy-making arenas such as the Intelligence Units in the Military and Police sector and the Securities Regulator in the Finance sector. In the Foreign 
Affairs sector a diarchy of the Minister and the President tends to appear, who compete with each other for control over patronage.

The changed global economic-financial context has undermined the role of patronage as an instrument for the mass organisational consolidation of parties through the extraction of resources from economic agencies. After the financial crisis of the Italian State and entry into the single currency, patronage has been transformed into an instrument for the connection of leaders and shareholder companies through the selection of top managers with professional qualification ensuring efficient management. There has been a retreat in patronage at the top levels: few hidden professionals and clients remain since resources to distribute have become scarce. Companies have become more professional at the lower and intermediate levels in order to adapt efficiently to the competitive pressures of globalised markets.

The restructuring of the central level of administration, the changes in the party system and the introduction of the direct election of heads of local executives have brought noticeable changes to the actors that control the expansion of patronage at the local level. Local executives have become dominant actors while in the past the national leaders of the Dc and the local party organisations of the Pci prevailed. In the Dc it was the role of pyramidal factions, networks of vertical exchange through which resources from agencies and public companies flowed from centre to periphery, that made local office holders weak and dependent on national leaders (Zuckerman 1979). The current scarcity of resources at the centre, the expansion of functions and resources for sub-national administrations, and the disappearance of the permanent control of the State by the Dc as the dominant party, have greatly weakened the strength of factional connections.

The legitimacy provided by the direct election of mayors and regional presidents and the clear reinforcement of executive power over administrative organisation have further weakened the factional links. Party system change facilitated the growth of local post-communist governors no longer controlled by a mass party that disappeared after the fall of communism. Members of the party in government at the subnational level have now autonomous control of patronage to satisfy local party networks. The Head of the Executive has become the dominant actor in subnational patronage processes. However, the rise of the subnational Presidents does not mean the ability to monopolise the distribution of positions, since there is competition from ministers seeking to extend their own networks from local ministerial departments to disaggregated administrations. In the new stratarchical configuration of Italian parties, subnational bosses offer the national leaders, who dispense patronage at the central level, an organisational base in exchange for lack of interference in the implantation of their local committees fed by public resources. 


\section{CONCLUSIONS: A matter of governmentness}

The empirical analysis reveals the persistent hold of parties on the Italian administration, while at the same time highlighting a clear cut discontinuity in the new parties' control mechanisms over the State. The wave of administrative and institutional reforms and the party system change prevented the return of colonisation as a specific mode of politicising the Italian administration which allowed the formation and reproduction of partitocrazia. The extraordinary collapse of old parties and the reshaping of the State in the 1990s demolished the two most characteristic traits of the partitocratic colonisation: continuously expanding scope and the clear pre-eminence of political links as a criterion in the selection of administrative elites by party organisations.

As far as the diffusion of patronage is concerned, the hypothesis on the fall of clientelism in affluent societies is confirmed (Kitschelt 2007). In the Italian case of comprehensive clientelism it was the crisis of old patterns of political competition that allowed the competitive pressures of the new global context of political economy to affect the State. The pressures of new global governance met with no resistance from organisational networks abandoned by parties in the process of disbanding. The exceptional break in the party system opened a window of opportunity for the technocratic elites that had guided the country's entry into Europe by restructuring the State (Sbragia 2001). The new economic constitution, arising from processes of privatisation and liberalisation, constituted an exogenous constraint for the new parties, whose patronage practices had to adapt to the culture of macro-economic stability institutionalised by membership of the European Union (Radaelli 2002). The more streamlined State, integrated in transnational economic institutional networks, prevented the reproduction of the inflationary tendencies of clientelism.

The study of patronage in Italy reveals the presence of organisational dynamics typical of parties in new democracies. Such a discovery is unsurprising if we understand the crisis of the 1990s as a regime crisis (Pasquino 2002) that allowed new parties lacking institutionalised mechanisms for coordinating the different functional arenas to enter government. As happens in new democracies, the concentration of power in the small nucleus of leaders straddling the roles of party in government and party executive acts as a cohesion-seeking strategy, compensating for the deficit of political loyalty in transitional contexts (Biezen 2005). Personal loyalties take the place of procedures such as mechanisms of party integration. The leaders become the only face of the party, since they control the distribution of the institutional resources that form the cement for fluid organisations.

Personalisation of patronage in Italy is an indicator of the under-institutionalisation of new parties subordinated to the personal power of the leaders. The organisational weakness of the new parties 
in government has placed them in a position of dependence with respect to members of the cabinet in the management of patronage. In personalising patronage, governors not only reinforce the policy making capacity of the cabinet, but above all they consolidate their power base through access to material public resources that are manipulated in order to feed the private networks that support their political activity ${ }^{4}$. As happens in new democracies, in Italy "political personalities make use of parties for their own ends, rather than act as the leaders of collective organisations of political actions" (Webb and White 2007, 359). With the new democracies, Italy shares both the generational factors of new parties that are governing without having first institutionalised their own organisational infrastructure, and the weakness of the public administration from which the private networks of leaders extract resources.

The unbearable financial weight of the "party governmentness" (Katz 1986) that characterised the partitocrazia has been replaced by the unbearable organisational lightness of the governmentness of new parties. Weak parties constitute an appendage of the personal power of their leaders in government. Patronage practised by new parties alternating in government has exacerbated the dysfunctions of the administrative systems still lacking strong interinstitutional linkages and networks that make a substantial contribution to policy coherence and effective public management (Torchia 2009). Patronage in Italy cannot guarantee an efficient link between parties and the system of governance, since responsible policy coordination requires procedures and institutionalised networks of communication rather than personal loyalties ${ }^{5}$.

According to Katz, in advanced democracies the political party "becomes a label by which a group of leaders is known and an organization for coordinating elite activity" (Katz 1990, 146). The party that no longer fulfils representative functions in society becomes an integrated network of office holders, a stable organisational structure of the governmental process within the State. The absence of institutionalisation renders Katz's definition invalid for the new Italian parties. The new Italian parties are only able to fulfil the "labelling function" typical in cases of atomisation in the party system.

The new organisations can only be defined as parties in the sense of Sartori's minimal definition, that is political groups identified by an official label that present at elections and are capable of placing through elections candidates for public office. As Sartori (1976) notes, this definition pays no attention to organisational requirements. In this definition the only cohesive element required is the label that gathers stable coalitions of office-holders and candidates. For Sartori (2005, 15-16), "before the advent of the mass parties it proper to speak of 'parties' (as stabilised coalitions of leaders) but not of the party system (as being a structured system)". Western European systems have been structured by the rise of the mass party which "resides in the linkage, in the fact that the 
party is made of its connecting network. The mass party may well remain loose and thus resemble a federation. Still, its costituent units are no longer persons but impersonal agencies; that is, the leaders are no longer above the party" (Sartori 2005, 15). As underlined by the turnover in party affiliations, which made the political offer particularly fluid after the crisis of pluralised polarism, leaders in Italy have returned to being above the parties. The infrastructure of the new organisations is not the institutionalised connecting network left by the mass parties to the cartel parties in stable systems. It was instead personal power that took the place of the connecting network in a context of systemic atomisation in which the party could not stay above the leaders, in the sense that "the party both outlasts its leaders and binds them to its logic of inertia" (Sartori $2005,12)$.

As new organisations that emerged after the exceptional crisis of the old system, Italian parties can only function as labels, coalitions of leaders incapable of structuring the actions of elites within governmental institutions through procedural mechanisms. It is the leaders who control the process of building parties that prosper as vehicles for professionals who use electoral success for personal profit (Lawson 2007). Rather than a devise that strengthens pre-existing party networks (Ware 1996), patronage can only strengthen Italian leaders. Old parties colonisation-oriented built extensive networks in a pervasive public sector as systems of organisational occupancy of the Italian society. Contemporary political leaders build new parties as labels cemented by institutional resources that feed private networks.

\footnotetext{
${ }^{1}$ On the long life of clientelism in Southern Italy, see Caciagli (2006).

${ }^{2}$ The patronage practices of the Northern League constitute the only exception to the dominant pattern. As a populist party the Northern League have met with considerable difficulties in recruiting top managers, since professionals have never offered their services to a party perceived as "not respectable".

${ }^{3}$ For a more detailed overview of the reduction of the politicisation of judicial offices see Guarnieri (2003). The quantitative weakness of parties is a result of the political control over only $1 / 3$ of the members of the CSM.

${ }^{4}$ As a result, corruption remains systemic but parties as agents of coordination and centralised protection of hidden exchanges have declined (Della Porta and Vannucci 2007).

${ }^{5}$ The investigation of the Italian case confirms the difficulties of governing efficiently and effectively for new parties in government suffering from organisational underdevelopment (Bolleyer 2008).
} 


\section{REFERENCES}

Amato, G. (1979). Le istituzioni per il governo dell'economia, in Graziano, L., Tarrow, S. (eds.), La crisi italiana, Einaudi, Torino.

Biezen, I. Van (2005). On the theory and practice of party formation and adaptation in new democracies, "European Journal of Political Research", 44, 1, 147-174.

Bolleyer, N. (2008). The organizational costs of public office, in Deschouwer, K. (ed.), New parties in government: in power for the first time, Routledge, London.

Caciagli, M. (2006). The Long Life of Clientelism in Southern Italy, in Kawata, J. (ed.), Comparing Political Corruption and Clientelism, Ashgate, Aldershot.

Cassese, S. (1993). Hypotheses on the Italian administrative system, "West European Politics", 16, 3, 316-328.

Cassese, S. (1999). Italy's Senior Civil Service: An Ossified World, in Page, E.C., Wright, V. (eds.), Bureaucratic Elites in Western European States: A Comparative Analysis of Top Officials in Eleven Countries, Oxford University Press, Oxford.

Citroni, G. (2009). Governo SpA: Pubblico e privato nelle società partecipate degli enti locali, "Rivista Italiana di Scienza Politica", 1, 87-112.

Cotta, M. (1996). La crisi del governo di partito all'italiana, in Cotta, M., Isernia, P. (eds), Il gigante dai piedi d'argilla, Il Mulino, Bologna.

Cotta, M., Verzichelli, L. (2000). Italy: From constrained coalitions to alternating governments?, in Muller, W.C., Strom, K. (eds.), Coalition Governments in Western Europe, Oxford University Press, Oxford.

D’Alimonte, R. (2005). Italy: A Case of Fragmented Bipolarism, in Gallagher, M., Mitchell, P. (eds.), The Politics of Electoral Systems, Oxford University Press, Oxford.

Della Porta, D., Vannucci, A. (2007). Mani impunite. Vecchia e nuova corruzione in Italia, Laterza, Roma-Bari.

Di Palma, G. (1979). The Available State: Problems of reform, "West European Politics", 2, 3, 149165.

Di Virgilio, A. (2006). Dal cambiamento dei partiti all'evoluzione del sistema partitico, in Morlino, L., Tarchi, M. (eds.), Partiti e caso italiano, Il Mulino, Bologna.

Golden, M.A. (2003). Electoral Connections: The Effects of the Personal Vote on Political Patronage, Bureaucracy and Legislation in Postwar Italy, "British Journal of Political Science", 33, 189-212.

Guarnieri, C. (2003). Giustizia e politica. I nodi della Seconda Repubblica, Il Mulino, Bologna. 
Katz, R.S. (1986). Party Government: A Rationalistic Conception, in Castles, F.G., Wildenmann, R. (eds.), Visions and Realities of Party Government, de Gruyter, Berlin.

Katz, R.S. (1990). Party as Linkage: A vestigial function?, "European Journal of Political Research", 1, 143-161.

Kitschelt, H. (2007). The demise of clientelism in affluent capitalist democracies, in Kitschelt, H., Wilkinson, S.I. (eds.), Patrons, Clients, or Policies? Patterns of Democratic Accountability and Political Competition, Cambridge University Press, Cambridge.

Kopecky, P., Scherlis, G. (2008). Party Patronage in Contemporary Europe, "European Review”, 16, 3, 355-371.

Lawson, K. (2007). When Parties Dedemocratize, in Lawson, K., Merkl, P.H. (eds.), When Parties Prosper: The Uses of Electoral Success, Lynne-Rienner, Boulder, CO.

Lewanski, R. (1999). Italian Administration in Transition, "South European Society \& Politics", 4, $1,97-131$.

Lupo, N. (2003). Dalla legge al regolamento. Lo sviluppo della potestà normativa del governo nella disciplina delle pubbliche amministrazioni, Il Mulino, Bologna.

Morlino, L. (1998). Democracy Between Consolidation and Crisis. Parties, Groups, and Citizens in Southern Europe, Oxford University Press, Oxford.

Natalini, A. (2006). Il tempo delle riforme amministrative, Il Mulino, Bologna.

Pasquino, G. (1995). La partitocrazia, in Pasquino, G. (ed.), La politica italiana. Dizionario critico 1945-1995, Laterza, Roma-Bari.

Pasquino, G. (2002). Il sistema politico italiano, Bononia University Press, Bologna.

Peters, B.G. (2008). The Napoleonic Tradition, "The Internation Journal of Public Sector Management", 21, 2, 118-132.

Radaelli, C. (2002). The Italian State and the Euro: Institutions, Discourse, and Policy Regimes, in Dyson, K. (ed.), European States and the Euro. Europeanization, Variation and Convergence, Oxford University Press, Oxford.

Sartori, G. (1976). Parties and Party Systems, Cambridge University Press, Cambridge.

Sartori, G. (2005). Party Types, Organisations and Functions, "West European Politics", 28, 1, 532.

Sbragia, A. (2001). Italy Pays for Europe: Political Leadership, Political Choice, and Institutional Adaptation, in Green Cowles, M., Caporaso, J., Risse, T. (eds.), Transforming Europe: Europeanization and domestic change, Cornell University Press, Ithaca, NY.

Sotiropoulos, D. (2004). Southern European Bureaucracies in Comparative Perspective, "West European Politics", 27, 3, 405-422. 
Torchia, L. (eds.) (2009). Il sistema amministrativo italiano nel XXI secolo, Il Mulino, Bologna. Verzichelli, L. (2009). Italy: the difficult road towards a more effective process of ministerial selection, in Dowding, K.M., Dumont, P. (eds.), The Selection of Ministers in Europe: Hiring and Firing, Routledge, London.

Ware, A. (1996). Political Parties and Party Systems, Oxford University Press, Oxford.

Webb, P., White, S. (2007). Political Parties in New Democracies: Trajectories of Development and Implications for Democracy, in Webb, P., White, S. (eds.), Party Politics in New Democracies, Oxford University Press, Oxford.

Zuckerman, A. (1979). The Politics of Faction: Christian Democratic Rule in Italy, Yale University Press, New Haven CT. 


\section{FIGURES}

Figure 1: Types of respondents

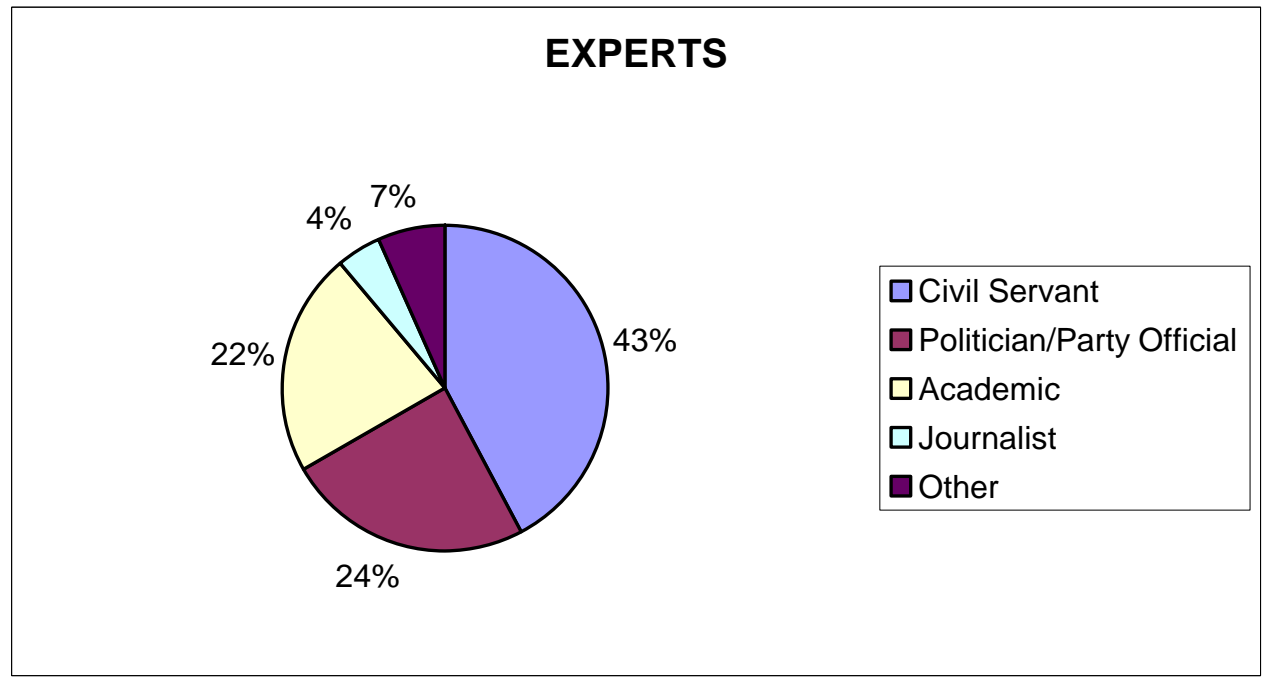

Figure 2: Range and Depth of patronage, by level of government 


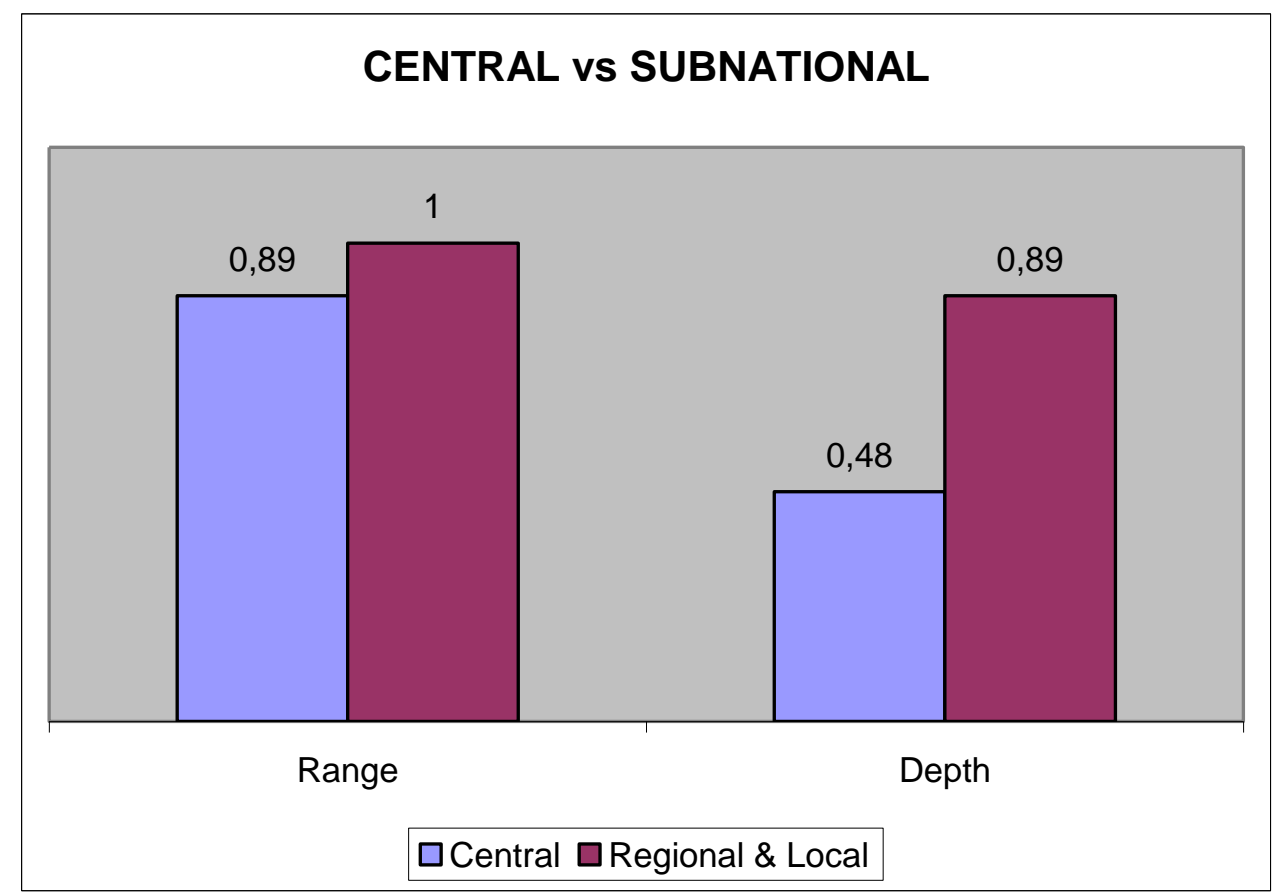

Figure 3: Motivations behind patronage practices

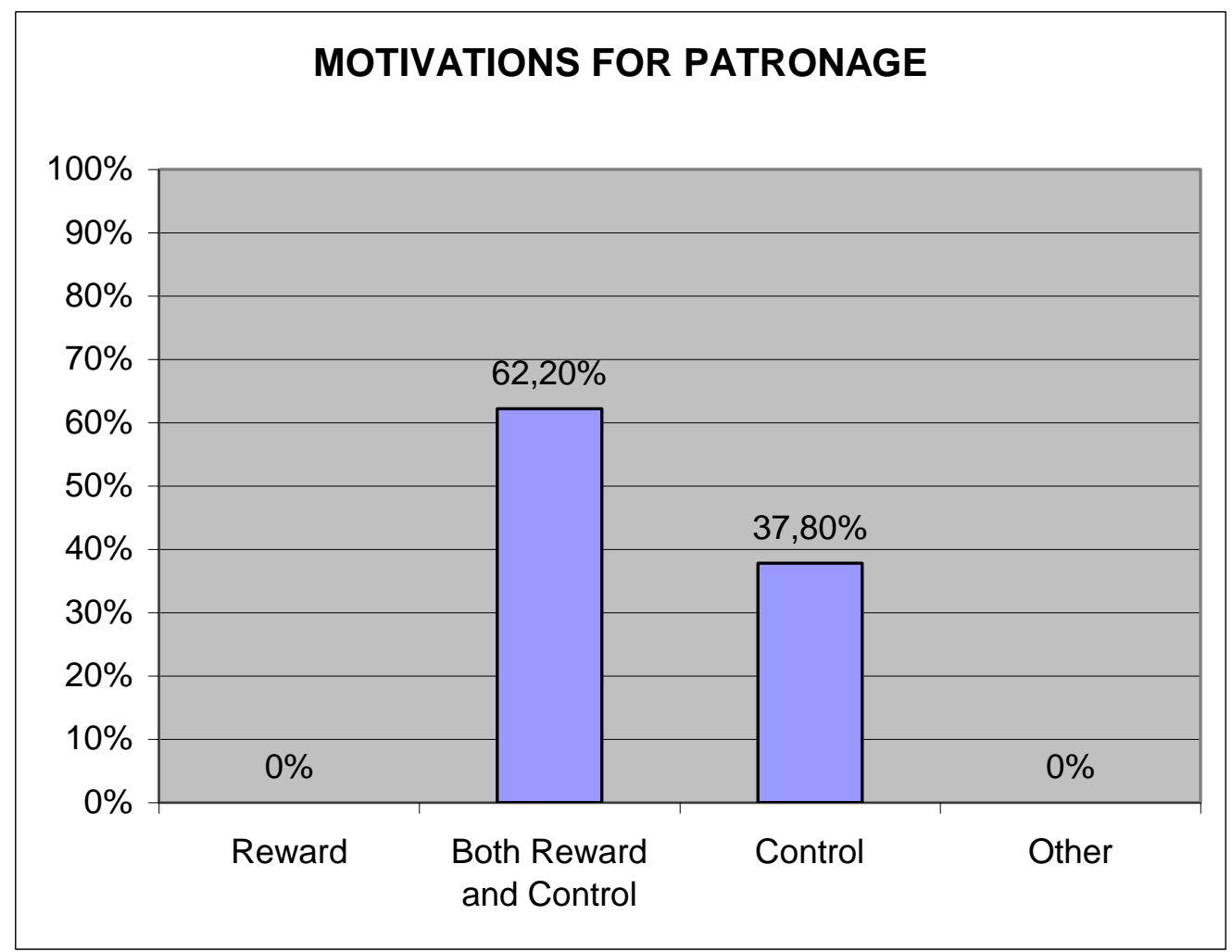

Figure 4: Appointees' Profile 


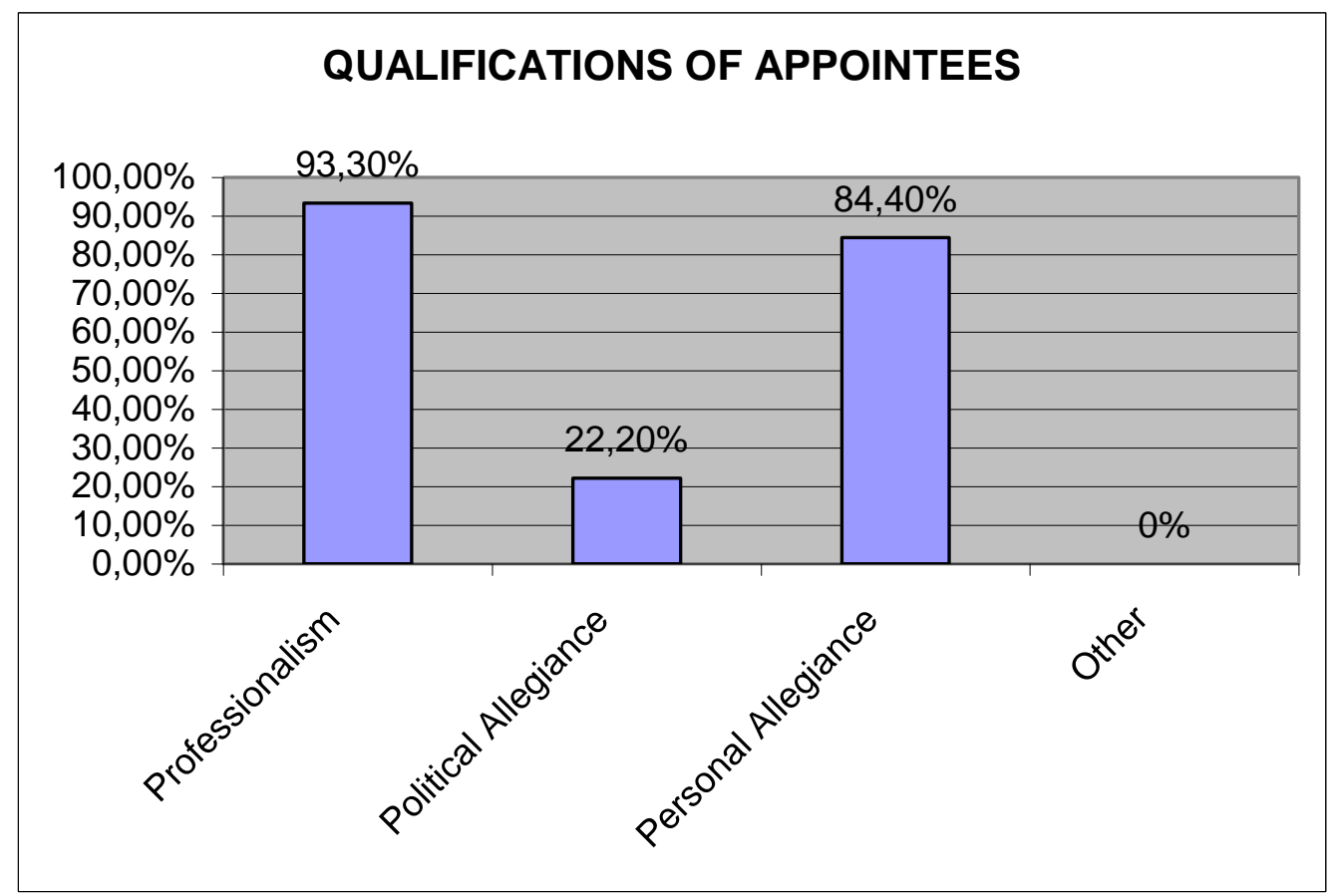

Figure 5: Majoritarian vs Consensual Appointments

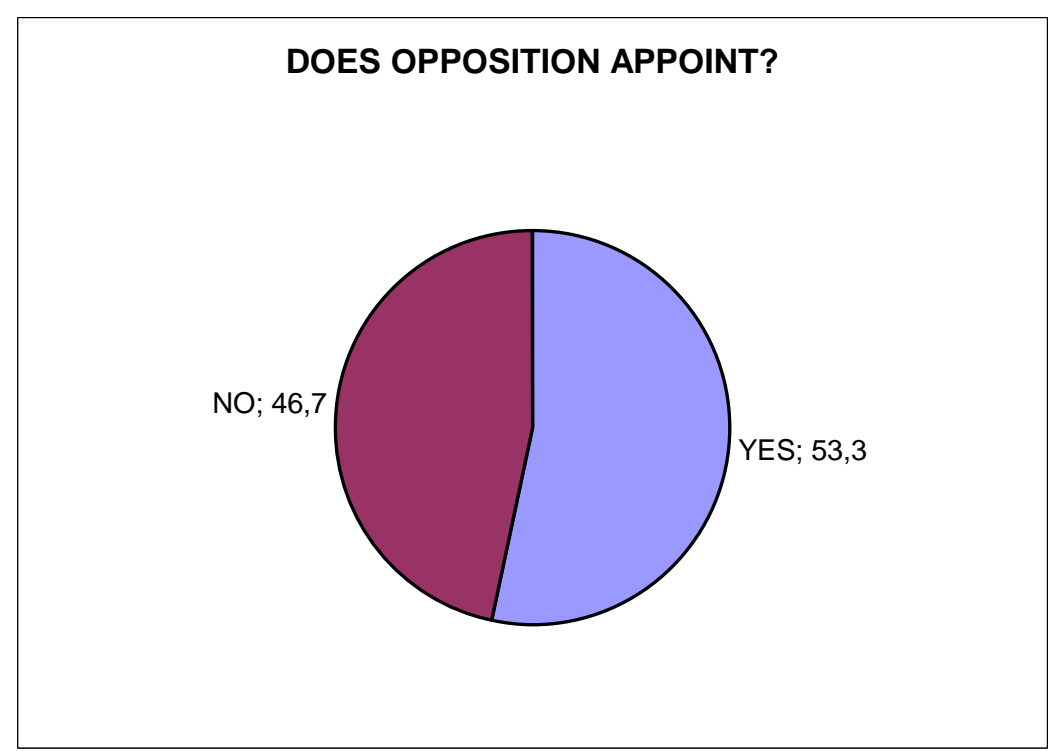




\section{TABLES}

Table 1: Number of General Government institutional units under the ESA95 (S.13) methodology (2008)

\begin{tabular}{|l|r|}
\hline INSTITUTIONS & N. \\
\hline State (Ministries, Prime Minister's Office, Fiscal Agencies, Constitutional Bodies) & 31 \\
\hline Research Bodies & 44 \\
\hline $\begin{array}{l}\text { Economic Bodies (Independent Administrative Authorities, Economic activities regulatory } \\
\text { bodies, Economic service producers, other bodies) }\end{array}$ & 36 \\
\hline Institutions providing cultural services and assistance & 61 \\
\hline Total Central Government & $\mathbf{1 7 2}$ \\
\hline Regions and Autonomous Provinces & 22 \\
\hline Provinces & 104 \\
\hline Municipalities & 8101 \\
\hline Producers of Health Services at Local level & 283 \\
\hline Economic bodies at Local level & 436 \\
\hline Institutions providing Education, Cultural Services and Assistance at Local level & 553 \\
\hline Other bodies & 769 \\
\hline Total Local Government & $\mathbf{1 0 2 6 8}$ \\
\hline Social Security Funds & 27 \\
\hline TOTAL & $\mathbf{1 0 4 6 7}$ \\
\hline
\end{tabular}

Source: Own elaboration. Data provided by ISTAT (Italian National Institute of Statistics)

Table 2: Scope and Reach of Patronage, by Policy Area and Institutional Types

\begin{tabular}{|c|c|c|c|c|}
\hline Policy Area & Ministries & NDAC & $\begin{array}{c}\text { Executing } \\
\text { Institutions }\end{array}$ & $\begin{array}{c}\text { Policy Area } \\
\text { Total }\end{array}$ \\
\hline Economy & 0,67 & 0,33 & 0,33 & 0,44 \\
\hline Finance & 0,67 & 0,22 & 0,22 & 0,37 \\
\hline Judiciary & 0,67 & 0,33 & 0,11 & 0,37 \\
\hline Media & 0,67 & 0,33 & 1,00 & 0,67 \\
\hline Military and Police & 0,33 & 0,33 & 0,11 & 0,26 \\
\hline Healthcare & 0,67 & 0,33 & 0,33 & 0,44 \\
\hline Culture and Education & 0,67 & 0,33 & 0,22 & 0,41 \\
\hline Foreign Services & 0,67 & 0,00 & 0,11 & 0,39 \\
\hline $\begin{array}{c}\text { Regional and Local } \\
\text { Administration }\end{array}$ & 0,67 & 1,00 & 1,00 & 0,89 \\
\hline Total & $\mathbf{0 , 6 3}$ & $\mathbf{0 , 4 0}$ & $\mathbf{0 , 3 8}$ & $\mathbf{0 , 4 7}$ \\
\hline
\end{tabular}


Table 3. Range of Patronage, by Policy Area and Institutional Types

\begin{tabular}{|c|c|c|c|c|}
\hline Policy Area & Ministries & NDAC & $\begin{array}{c}\text { Executing } \\
\text { Institutions }\end{array}$ & Policy Area Total \\
\hline Economy & 3 & 3 & 3 & 1,00 \\
\hline Finance & 3 & 2 & 2 & 0,78 \\
\hline Judiciary & 3 & 3 & 1 & 0,78 \\
\hline Media & 3 & 3 & 3 & 1,00 \\
\hline Military and Police & 1.5 & 3 & 1 & 0,61 \\
\hline Healthcare & 3 & 3 & 3 & 1,00 \\
\hline Culture and Education & 3 & 3 & 2 & 0,89 \\
\hline Foreign Services & 3 & n.a. & 1 & 0,67 \\
\hline Total Central Level & $\mathbf{0 , 9 4}$ & $\mathbf{0 , 9 5}$ & $\mathbf{0 , 6 7}$ & $\mathbf{0 , 8 5}$ \\
\hline $\begin{array}{c}\text { Regional and Local } \\
\text { Administration }\end{array}$ & 3 & 3 & 3 & 1,00 \\
\hline Total & $\mathbf{0 , 9 4}$ & $\mathbf{0 , 9 6}$ & $\mathbf{0 , 7 0}$ & $\mathbf{0 , 8 9}$ \\
\hline
\end{tabular}

Table 4. Depth of Patronage, by Policy Area and Institutional Types

\begin{tabular}{|c|c|c|c|c|}
\hline Policy Area & Ministries & NDAC & $\begin{array}{c}\text { Executing } \\
\text { Institutions }\end{array}$ & Policy Area Total \\
\hline Economy & 2 & 1 & 1 & 0,44 \\
\hline Finance & 2 & 1 & 1 & 0,44 \\
\hline Judiciary & 2 & 1 & 1 & 0,44 \\
\hline Media & 2 & 1 & 3 & 0,67 \\
\hline Military and Police & 2 & 1 & 1 & 0,44 \\
\hline Healthcare & 2 & 1 & 1 & 0,44 \\
\hline Culture and Education & 2 & 1 & 1 & 0,44 \\
\hline Foreign Services & 2 & n.a. & 1 & 0,50 \\
\hline Total Central Level & $\mathbf{0 , 6 7}$ & $\mathbf{0 , 3 3}$ & $\mathbf{0 , 4 2}$ & $\mathbf{0 , 4 8}$ \\
\hline $\begin{array}{c}\text { Regional and Local } \\
\text { Administration }\end{array}$ & 2 & 3 & 3 & 0,89 \\
\hline Total & $\mathbf{0 , 6 7}$ & $\mathbf{0 , 4 2}$ & $\mathbf{0 , 4 8}$ & $\mathbf{0 , 5 3}$ \\
\hline
\end{tabular}


Table 5: The Evolution of Patronage over time, Patterns

\begin{tabular}{|c|l|}
\hline Sectors & $\begin{array}{l}\text { From consensual arrangements to polarisation: } \\
\text { Decline of control over Judicial Offices }\end{array}$ \\
\hline Institutional Types & $\begin{array}{l}\text { Bipolarism and NPM reforms: } \\
\text { Expansion of patronage in the ministerial domain }\end{array}$ \\
\hline Range & $\begin{array}{l}\text { Restructuring of the administrative system: } \\
\text { Decline at Central level (privatizations), Expansion at Local level (corporatization) }\end{array}$ \\
\hline Depth & $\begin{array}{l}\text { Patronage in retreat under pressures from transnational networks: } \\
\text { From deep segmentation to control of top management in extra-ministerial domains }\end{array}$ \\
\hline Logic & $\begin{array}{l}\text { More Control; Less Clientelism; } \\
\text { Reward still significant, particularly at local level }\end{array}$ \\
\hline Mechanisms & $\begin{array}{l}\text { Collapse of Political Link and Rise of Personalisation; Growth of Head of the } \\
\text { Executive's influence at all levels; Territorialization of subnational patronage }\end{array}$ \\
\hline
\end{tabular}

